\title{
Synthesis of Novel Quinazoline Derivatives via Pyrimidine ortho-Quinodimethane
}

\author{
R. Chioua ${ }^{1 * *}$, F. Benabdelouahab ${ }^{1}$, M. Chioua $^{2}$, R. Martínez-Alvarez ${ }^{2}$ and A. Herrera \\ Fernández ${ }^{2}$.
}

${ }^{1}$ Département de Chimie, Université Abdelmalek Essaâdi, Faculté des Sciences, B.P 2121, Tétouan, Morocco. Tel. (+212) 399724 23, Fax (+212) 39994500.

2 Departamento de Química Orgánica I, Facultad de Ciencias Químicas, Universidad Complutense, E28040, Spain. Tel. (+34) 91-3944205, Fax (+34) 91-3944103, E-mail aherrera@eucmax.sim.ucm.es

* Author to whom correspondence should be addressed; E-mail rchioua@ hotmail.com

Received: 24 September 2001; in revised form: 3 July 2002 / Accepted: 8 July 2002 / Published: 31 July 2002

\begin{abstract}
The [4+2] cycloaddition between 2,4-diphenylpyrimidine ortho-quinodimethane and dimethyl acetylenedicarboxylate leads to 2,4-diphenylquinazoline-6,7-dicarboxylate (6). 2,4-Diphenylfuro[3,4-g]quinazoline-6,8-dione (7) is also obtained by basic hydrolysis of compound $\mathbf{6}$, followed by the closure of the resulting diacid in acetic anhydride.
\end{abstract}

Keywords: [4+2] Cycloaddition, Diels-Alder adduct, dimethyl 2,4-diphenylquinazoline dicarboxylate.

\section{Introduction}

The presence of a pyrimidine nucleus in many heterocyclic compounds, for example, the quinazolines, often leads to very interesting biological and pharmaceutical activities [1,2] so many methods for preparing quinazolines are reported in the literature $[3,4]$. In this work, we have developed an original method to prepare novel quinazoline derivatives based on cycloaddition between 2,4disubstituted pyrimidine ortho-quinodimethanes and suitable dienophiles [5]. 


\section{Results and Discussion}

The 2,4-diphenylpyrimidine ortho-quinodimethanes 4 were obtained according to a reported method [5]. The reaction of cyclobutanone (1) with benzonitrile (2) and triflic anhydride $\left(\mathrm{Tf}_{2} \mathrm{O}\right)$ leads to the formation in one step of 3,5-diphenyl-2,4-diaza-bicyclo[4.2.0]octa-1(6),2,4-triene (3) in moderate yield.

Heating compound 3 in $o$-dichlorobenzene (ODCB) at $180^{\circ} \mathrm{C}$ leads to the in situ generation of the extremely reactive pyrimidine diene 4 , which was further reacted with dimethyl acetylenedicarboxylate (5), via a [4+2]cycloaddition, to give the Diels-Alder adduct dimethyl 2,4-diphenylquinazoline-6,7dicarboxylate (6) in $50 \%$ yield in which loss of $\mathrm{H}_{2}$ has occured.

\section{Scheme 1}

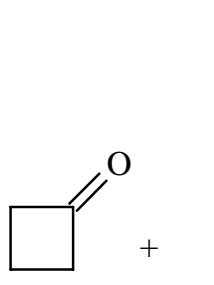

1<smiles>N#Cc1ccccc1</smiles>

2<smiles>Cc1nc(-c2ccccc2)nc(-c2ccccc2)c1C</smiles>

3

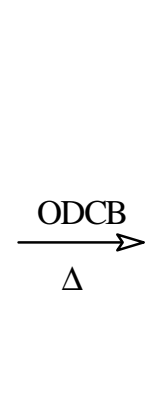

$\Delta$<smiles>COC(=O)C#CC(=O)OC</smiles><smiles>O=C1OC(=O)c2cc3c(-c4ccccc4)nc(-c4ccccc4)nc3cc21</smiles>

The diester 6 when treated with a $1 \mathrm{~N}$ solution of $\mathrm{NaOH}$, afforded the expected 2,4diphenylquinazoline-6,7-dicarboxylic acid in quantitative yield after two hours of stirring at $80^{\circ} \mathrm{C}$. Subsequent heating of the diacid in acetic anhydride leads to 2,4-diphenylfuro[3,4-g]quinazoline-6,8dione (7) (Scheme 1).

\section{Conclusions}

We have presented an easy method for the formation of dimethyl 2,4-diphenylquinazoline-6,7dicarboxylate. Basic hydrolysis of this diester followed by the closure of the resulting diacid in acetic anhydride gives 2,4-diphenylfuro[3,4-g]quinazoline-6,8-dione. This result opens an access for the 
synthesis of other interesting derivatives such as the $\beta$-amino acid derivatives of quinazoline which could exhibit interesting biological activity. The synthesis of these compounds is underway in our laboratory.

\section{Acknowledgements}

We are grateful to the Agencia Española de Cooperación Internacional (AECI) for financial support. We thank the Centro de Espectroscopía de la UCM for determining NMR and mass spectra.

\section{Experimental}

\section{General}

${ }^{1} \mathrm{H}$ - and ${ }^{13} \mathrm{C}$-NMR spectra were obtained using Varian VXR 300S, Bruker AC-200 and Bruker AM300 instruments. Melting points were determined on a Gallenkamp apparatus and are uncorrected. I.R spectra were recorded on a Shimadzu FTIR 8300. The $70 \mathrm{eV}$ mass spectra were recorded using a HP5989A quadrupole instrument (Hewlett Packard, Palo Alto, CA, USA) with a source temperature of $250^{\circ} \mathrm{C}$.

Synthesis of dimethyl 2,4-diphenylquinazoline-6,7-dicarboxylate (6).

2,4-Diphenylcyclobutapyrimidine $(3,200 \mathrm{mg}, \quad 0.77 \mathrm{mmol})$ was refluxed with dimethyl acetylenedicarboxylate $(5,0.2 \mathrm{~mL})$ in $o$-dichlorobenzene $(5 \mathrm{~mL})$ at $180^{\circ} \mathrm{C}$ for $48 \mathrm{~h}$. The solvent was removed under vacuum and the residue was subjected to silica gel chromatography with hexane/ethyl acetate (8:2) as the eluent. Compound (6) was thus obtained as a white solid (150 mg, $50 \%$ ), mp (from hexane): $156-158{ }^{\circ} \mathrm{C} ;{ }^{1} \mathrm{H}-\mathrm{NMR}\left(\mathrm{CDCl}_{3}\right) \delta: 3.86\left(\mathrm{~s}, 3 \mathrm{H}, \mathrm{CO}_{2} \mathrm{CH}_{3}\right), 3.94\left(\mathrm{~s}, 3 \mathrm{H}, \mathrm{CO}_{2} \mathrm{CH}_{3}\right), 7.48(\mathrm{~m}, 3 \mathrm{H}$, $\left.\mathrm{C}_{6} \mathrm{H}_{5}\right), 7.58\left(\mathrm{~m}, 3 \mathrm{H}, \mathrm{C}_{6} \mathrm{H}_{5}\right), 7.83\left(\mathrm{~m}, 2 \mathrm{H}, \mathrm{C}_{6} \mathrm{H}_{5}\right), 8.36(\mathrm{~s}, 1 \mathrm{H}, \mathrm{H}-5), 8.52$ (s, 1H, H-8), 8.64 (m, 2H, $\left.\mathrm{C}_{6} \mathrm{H}_{5}\right) ;{ }^{13} \mathrm{C}-\mathrm{NMR}\left(\mathrm{CDCl}_{3}\right)$ \&: 53.05, 53.18, 128.78, 129, 129.13, 129.82, 130.37, 130.51, 130.72, 131.47, 137.79, 138.13, 155, 167.03, 167.16; IR (KBr) cm ${ }^{-1}: 1728,1560,1294,1261,1157$; MS (m/z): $398\left(\mathrm{M}^{+\bullet}, \mathrm{C}_{24} \mathrm{H}_{18} \mathrm{~N}_{2} \mathrm{O}_{4}, 78 \%\right), 339$ (100\%), 367 (31\%), 351 (42\%), 280 (64\%).

Synthesis of 2,4-diphenylfuro[3,4-g]quinazoline-6,8-dione (7).

Dimethyl 2,4-diphenylquinazoline dicarboxylate (6) (150 mg, $0.37 \mathrm{mmol})$ and $1 \mathrm{~N} \mathrm{NaOH}$ solution $(2 \mathrm{~mL})$ in methanol $(5 \mathrm{~mL})$ were heated for $2 \mathrm{~h}$; after cooling the solution was concentrated under vacuum and the residue was dissolved in water $(5 \mathrm{~mL})$ and acidified with $2 \mathrm{~N} \mathrm{HCl}$ solution. The resulting suspension was filtered to give 2,4-diphenylquinazoline-6,7-dicarboxylic acid (130 mg, 96 $\%$ ), which was dissolved in acetic anhydride $(5 \mathrm{~mL})$ and heated under reflux for $2 \mathrm{~h}$. After cooling, the product precipitated and was isolated by filtration $(115 \mathrm{mg}, 93 \%$ ), $\mathrm{mp}$ (from acetic anhydride): 280$282{ }^{\circ} \mathrm{C} ;{ }^{1} \mathrm{H}-\mathrm{NMR}\left(\mathrm{DMSO}_{-} \mathrm{d}_{6}\right) \delta: 7.6\left(\mathrm{~m}, 3 \mathrm{H}, \mathrm{C}_{6} \mathrm{H}_{5}\right), 7.77\left(\mathrm{~m}, 3 \mathrm{H}, \mathrm{C}_{6} \mathrm{H}_{5}\right), 8\left(\mathrm{~m}, 2 \mathrm{H}, \mathrm{C}_{6} \mathrm{H}_{5}\right), 8.35(\mathrm{~s}, 1 \mathrm{H}$, 
H-5), 8.53 (s, 1H, H-8), 8.69 (m, 2H, $\left.\mathrm{C}_{6} \mathrm{H}_{5}\right)$; IR (KBr) cm $\mathrm{cm}^{-1}: 1716,1687,1616,1600,1388,1244$, 1215, 1170; $\mathrm{MS}(\mathrm{m} / \mathrm{z}): 352\left(\mathrm{M}^{+\bullet}, \mathrm{C}_{22} \mathrm{H}_{12} \mathrm{~N}_{2} \mathrm{O}_{3}, 43 \%\right), 351(18 \%), 283$ (21\%) 280 (74\%), 280 (74 $\%), 149(11 \%), 105(14 \%)$.

\section{References}

1. Szarics, E; Nyikos, L; Barabas, P; Kovacs, I; Skuban, N; Temesvarine-Major, E; Egyed, O; Nagy, P.I.; Kokosi, J; Takacs-Novak, K; Kardos, J. Mol. Pharmacol., 2001, 59, 920-928.

2. Sielecki, T.M.; Johnson, T.L.; Liu, J; Muckelbauer, J.K.; Grafstrom, R.H.; Cox, S.; Boylan, J.; Burton, C.R.; Chen, H.Y.; Smallwood, A.; Chang, C.H.; Boisclair, M.; Benfield, P.A.; Trainor, G.L.; Seitz, S.P. Bioorg. Med. Chem. Lett., 2001, 11, 1157-1160.

3. Hanusek, J; Hejtmankova, L; Kubicova, L; Sedlak, M. Molecules, 2001; 6, 323-337.

4. Shibuya, I; Gama, Y; Shimizu, M. Heterocycles, 2001, 55, 381-386.

5. Herrera, A; Martinez, R; Gonzalez, B; Illescas, B; Martin, N; Seoane, C. Tetrahedron Lett., 1997, $38,4873-4876$.

Sample Availability: Available from the authors.

(C) 2002 by MDPI (http://www.mdpi.org). Reproduction is permitted for noncommercial purposes. 